\title{
PELATIHAN STUDI KELAYAKAN USAHA BAGI PELAKU USAHA MIKRO KECIL DAN MENENGAH DI KELURAHAN TEMBELING TANJUNG KECAMATAN TELUK BINTAN KABUPATEN BINTAN
}

\author{
Business Feasibility Study Training for Micro Small And Medium Enterprises In \\ Kelurahan Tembeling Tanjung, Kecamatan Teluk Bintan, Bintan
}

Fatahurrazak $^{1 *}$, Muhammad Idris DM²

Jurusan Akuntansi, Fakultas Ekonomi Universitas Maritim Raja Ali Haji - Tanjungpinang Jurusan Manajemen, Fakultas Ekonomi Universitas Maritim Raja Ali Haji - Tanjungpinang

*Korespondensi : faturajafatur@gmail.com

\begin{abstract}
ABSTRAK
Setiap usaha yang akan dilaksanakan seharusnya melalui suatu fase telaah untuk melihat apakah usaha tersebut layak atau tidak untuk dilaksanakan, hal ini perlu dilakukan untuk mengantisipasi kemungkinan-kemungkinan terjadinya kerugian. Untuk perusahaan dengan modal yang besar wajib dilakukan analisis kelayakan usaha, dan tidak menutup kemungkinan juga dilakukan bagi perusahaan kecil menengah. Pengabdian ini dilaksanakan di Kelurahan Tembeling Tanjung Kecamatan Teluk Bintan Kabupaten Bintan Provinsi Kepulauan Riau yang diikuti oleh 34 Pelaku Usaha yang tersebar di Kecamatan Teluk Bintan Kabupaten Bintan. Pelaku usaha ini telah memiliki berbagai macam usaha namun sebelumnya mereka tidak pernah melakukan analisis terhadap usaha yang akan mereka jalankan, dan pedoman usaha mereka adalah melihat orang lain berusaha dan lancar kemudian mengasumsikan pada usaha mereka, padahal hal tersebut belum tentu sama. Pengabdian ini dilaksanakan dalam bentuk pelatihan dan Praktek. Dalam pelatihan ini ditekankan bagaimana memahami aspekaspek seperti aspek bahan baku, aspek pasar, dan aspek keuangan, SWOT, dan juga ditambahkan bagaimana cara menghitung harga pokok perunit secara benar dan menentukan penjualan paling minimal untuk menetapkan batas target penjualan agar usaha tidak mengalami kerugian, serta menghitung berapa lama modal meraka akan kembali.
\end{abstract}

Kata Kunci : Pelatihan, Studi Kelayakan Usaha, UMKM

\begin{abstract}
Every business that will be implemented should go through a review phase to see whether the business is feasible or not to be carried out, this needs to be done to anticipate the possibility of losses. For companies with large capital, business feasibility analysis must be done, and it is also possible for small and medium companies to do this. This dedication was carried out in Tembeling Tanjung Sub-District, Teluk Bintan District, Bintan Regency, Riau Islands Province, which was participated by 34 Business Actors spread in Bintan Bay District, Bintan Regency. These business actors already have a variety of businesses but before that, they have never done an analysis of the business they are going to run, and their business guideline is to see other people try and smoothly then assume their business, even though it is not necessarily the same. This service is carried out in the form of training and practice. In this training, it was emphasized how to understand aspects such as raw material aspects, market aspects, and financial aspects, SWOT, and also added how to calculate per-unit cost of goods
\end{abstract}


correctly and determine the minimum sales to set sales target limits so that businesses do not experience losses, and calculate how long their capital will return.

\section{Keywords: Business Feasibility Study, Training, UMKM}

\section{PENDAHULUAN}

Sebagian besar penduduk Indonesia dalam aktivitas kita sehari-hari tak lepas dari berbagai layanan dan barang hasil kreasi pelaku usaha kecil dan menengah yang dimulai dengan melakukan aktivitas pagi hari ketika sarapan kita mencari berbagai makanan ringan yang dijual UMKM, membeli berbagai kebutuhan pokok sehari-hari di warung dekat rumah, sampai menitipkan anak-anak meraka di playgroup terdekat yang juga merupakan UMKM. Dan yang menarik di era digital saat ini yang dikenal dengan revolusi industry 4.0, ada yang tidak memiliki toko secara fisik, serta memasarkan produkproduk mereka secara secara online, walaupun belum memiliki izin usaha. Pelaku usaha dengan karakteristik tersebut dapat ditemukan disekitar kita baik itu saudara, tetangga, teman atau kita sendiri. Kita tidak bisa menganggap remeh usaha yang dilakukan oleh UMKM, dan walaupun kelihatan kecil, tapi hasil yang mereka lakukan dapat mendongkrak pergerakan ekonomi Indonesia

Kementerian Koperasi dan UKM RI melaporkan bahwa secara jumlah unit, UMKM memiliki pangsa sekitar 99,99\% (62.9 juta unit) dari total keseluruhan pelaku usaha di Indonesia (2017), sementara usaha besar hanya sebanyak $0,01 \%$ atau sekitar 5.400 unit. Usaha Mikro menyerap sekitar 107,2 juta tenaga kerja (89,2\%), Usaha Kecil 5,7 juta $(4,74 \%)$, dan Usaha Menengah 3,73 juta $(3,11 \%)$; sementara Usaha Besar menyerap sekitar 3,58 juta jiwa. Artinya secara gabungan UMKM menyerap sekitar 97\% tenaga kerja nasional, sementara Usaha Besar hanya menyerap sekitar 3\% dari total tenaga kerja nasional.

Di Indonesia Undang-Undang yang mengatur tentang UMKM adalah UU No. 20/2008, dalam UU tersebut UMKM dijelaskan sebagai: "perusahaan kecil yang dimiliki dan dikelola oleh seseorang atau dimiliki oleh sekelompok kecil orang dengan jumlah kekayaan dan pendapatan tertentu." Berikut kriteria kekayaan dan pendapatan di dalam UU tersebut. Usaha Mikro, asset maksimal Rp 50juta, dan omzet maksimal 300juta. Usaha Kecil, asset Rp 50juta-500juta, dan omzet Rp 300juta - Rp 2,5milyard. Usaha Menengah, asset Rp 50juta-10milyard, dan omzet Rp 2,5milyard - Rp 10milyard. Usaha Besar, asset di atas Rp 10milyard, dan omzet di atas Rp 10milyard

Usaha ini dapat dikategorikan ke dalam Usaha Mikro apabila memiliki aset maksimal Rp 50 juta dan omzet maksimal Rp 300 juta per tahun atau sekitar Rp1.000.000 per hari (asumsi beroperasional aktif selama 300 hari/tahun); sementara batas atas omzet untuk Usaha Kecil adalah sekitar Rp8,3 juta per hari; dan batas atas omzet Usaha Menengah adalah sekitar Rp167juta per hari. Kini kita dapat menentukan sendiri apakah usaha yang kita jalankan termasuk dalam usaha skala mikro, kecil, atau menengah dengan merujuk pada kriteria UMKM di atas.

Jumlah UMKM cukup banyak apabila dibandingkan dengan jumlah unit Usaha Besar yang hanya sekitar 5.000 unit $(0,01 \%)$ dari 63 juta unit usaha, dengan bidang usaha berdasarkan paparan dari perwakilan BPS di suatu FGD yang pernah kami selenggarakan bersama Kementerian Koperasi dan UKM RI (pada 31 Oktober 2017), disampaikan bahwa secara umum bidang usaha UMKM dibagi menjadi dua kelompok besar yaitu Pertanian dan NonPertanian. Jumlah usaha di kelompok Pertanian dihitung melalui Sensus Pertanian 2013 (bukan survei); sementara yang non-pertanian dihitung melalui Sensus Ekonomi 2016. Kondisi ini 
membuat perhitungan total jumlah UMKM menjadi agak membingungkan, karena tidak bisa jumlah angka usaha pertanian (2013) ditambahkan dengan jumlah usaha non-pertanian (2016). Terlebih, pada Sensus Ekonomi 2016, BPS mengkategorikan publikasi datanya ke dalam 2 kelompok: Usaha Mikro Kecil (UMK) dan Usaha Menengah Besar (UMB); jadi kita tidak bisa mengetahui rincian per skala mikro, kecil, menengah, dan besar. Untuk melakukan ini mungkin butuh akses ke database mentah hasil Sensus Ekonomi 2016 tersebut.

Kegiatan produksi merupakan kegiatan yang berhubungan dengan penciptaan/pembuatan barang, jasa atau kombinasinya, melalui proses transformasi dari masukan sumber daya produksi menjadi keluaran yang diinginkan. Melalui kegiatan produksi, segala sumber daya masukan perusahaan diintegrasikan untuk menghasilkan keluaran yang memiliki nilai tambah. Produk yang dihasilkan dapat berupa barang atau akhir, barang setengah jadi ataupun jasa. Bagi perusahaan berorientasikan laba, produk ini selanjutnya dijual untuk memperoleh keuntungan dan sumber dana yang baru bagi kegiatan operasi berikutnya. Kegiatan produksi merupakan kegiatan kompleks, tidak saja mencakup pelaksanaan fungsi manajemen dalam mengkordinasikan berbagai kegiatan atau bagian dalam mencapai tujuan produksi, tetapi juga mencakup kegiatan teknis untuk menghasilkan suatu produk yang memenuhi spesifikasi yang diinginkan, dengan proses produksi yang efisien dan efektif serta dengan mengantisipasi perkembangan teknologi dan kebutuhan konsumen di masa yang akan datang. Oleh karena itu, pengetahuan yang baik tentang manajemen produksi perlu dimiliki oleh semua pihak yang terlibat langsung dalam proses pembuatan produk sesuai dengan peranan masing-masing (Wiagustini 2010).
Selain untuk memenuhi kebutuhan manusia adalah untuk mendapatkan keuntungan yang layak, maka suatu organisasi dapat mempertahankan hasil produksinya agar berkembang dan maju, untuk mencapai tujuan tersebut setiap masyarakat harus mempelajari konsep produktivitas yang tinggi, yang dalam hal ini akan melibatkan seseorang ketua kelompok untuk berkoordinasi kepada seluruh elemen yang ada untuk mendukung dalam pembentukan produktivitas dan pemasaran (Ikatan Akuntan Indonesia 2016).

Meningkatkan Produktivitas dan Pemasaran yang layak memang tak semudah yang kita bayangkan, produkproduk yang dibuat oleh masyarakat harus memiliki standarisasi agar produk tersebut dapat diterima di pasar nasional maupun internasional, hal ini menjadi sebuah tantangan bagi pemerintah Kabupaten Bintan khususnya untuk melakukan indentifikasi setiap pelaku Usaha Ekonomi Masyarakat Produktif yang ada di Kabupaten Bintan, untuk dikaji permasalahan yang ada di lapangan di dalam mengembangkan usaha yang mereka jalani, serta memberikan pelatihan-pelatihan dan penguatan bagi pelaku Usaha Ekonomi Masyarakat Produktif agar produksi dan efektifitas kerja mereka dapat berkembang dengan maksimal, sehingga dapat meningkatkan kesejahteraan masyarakat, sesuai dengan visi dan misi Kabupaten Bintan, yaitu terwujudnya Kabupaten Bintan yang Madani dan Sejahtera melalui pencapaian Bintan gemilang 2025.

Adapun pelaku usaha pada program pengabdian masyarakat ini adalah para Pelaku Usaha Kecil dan Menengah di Kelurahan Tembeling Tanjung Kecamatan Teluk Bintan yang telah menjalankan usaha lebih dari 4 tahun dengan bentuk usaha yang beraneka macam, seperti usaha kerupuk ikan, warung kelontong, bengkel, perkebunan palawija, tanaman hias, gorengan, menjahit, konter HP/pulsa, dan warung 
nasi.

Pada awalnya pelaku usaha ini dalam aktifitasnya didanai dari PNPM (Program Nasional Pemberdayaan Masyarakat), dan sejak PNPM tidak diperpanjang lagi pada desember 2014, maka aset PNPM selanjutnya dikelola oleh UPK (Unit Pengelola Kegiatan) sampai saat ini. Adapun sistem kerja penyaluran dana pinjaman ini adalah diberikan dalam bentuk pelaku usaha yang terdiri dari 5-10 orang atau lebih setiap kelompoknya, dan dana pinjaman akan diberikan kepada kelompok dalam jumlah yang sama dengan jangka waktu pengembalian selama 10 bulan - satu tahun dengan tingkat bunga yang rendah. Ketua kelompok bertanggung jawab dalam mengembalikan pinjaman secara keseluruhan dan tidak boleh menunggak, dan biasanya ketua kelompok punya cara sendiri untuk memastikan tidak ada anggota kelompoknya yang mangkir dalam membayar pinjaman mereka, dan UPK biasanya akan memberikan sanksi tertentu apabila ada pelaku yang menunggak dalam melakukan pembayaran, seperti mendahulukan pencairan untuk pelaku yang masuk dalam kategori lancar sebagai penghargaan bagi kelompok tersebut yang juga sering disebut Insentif Pembayaran Tepat Waktu (IPTW).

Pelaku dalam hal ini bukanlah mereka yang menjalankan bisnis yang sama yang tergabung dalam kelompok, namun dibentuk kelompok hanyalah untuk mempermudah kontrol oleh UPK dan sebagai tempat dan sarana berkomunikasi bagi setiap anggota kelompok termasuk bimbingan dan pembinaan yang diberikan, sehingga anggota kelompok ini haruslah mereka tinggal di daerah yang berdekatan sehingga memudahkan untuk berkomunikasi, walaupun bisnis yang mereka jalankan tidak sama.

Selain itu tanggungjawab terhadap dana yang dipinjamkan dari UPT adalah tanggungjawab setiap anggota kelompok yang meminjam, walaupun demikian apabila ada salah satu anggota kelompok yang gagal dalam membayar angsuran pinjaman, maka itu dianggap kegagalan kelompok, dan jika sekali saja kelompok gagal atau terlambat dalam membayar angsuran maka sudah termasuk pada kategori tidak lancar sehingga akan mengganggu untuk pencairan pada periode berikutnya.

Berdasarkan hasil survey yang dilakukan terhadap pelaku usaha yang masuk dalam kategori lancar (IPTW) ternyata pelaku tersebut sebagian besar tidak menyelenggarakan pencatatan apalagi membuat pembukuan yang benar sehingga sangat sulit untuk mengukur dan mengetahui apakah usaha yang dijalankan memberikan keuntungan atau kerugian. Bagi mereka dari hasil penjualan atau jasa yang diberikan sudah dapat menutupi angsuran hutang dan kebutuhan seharihari, itu sudah dianggap berhasil dan mencukupi kebutuhan primer. Akibatnya pengembangan usaha ke arah yang lebih besar akan sangat sulit untuk diwujudkan, dan ditambah lagi dengan tidak adanya membuat perencanaan untuk mengembangkan usahanya.

Hal yang tidak kalah pentingnya yang selalu dilanggar adalah para pelaku usaha ini tidak menerapkan konsep entitas, yaitu memisahkan memisahkan antara aset perusahaan dengan aset pribadi, dan yang terjadi adalah di mana aset perusahaan juga adalah aset pribadi sehingga akan sangat sulit dalam penyusunan laporan keuangan termasuk kesulitan dalam menghitung harga pokok produksi secara benar karena asset usaha masih bercampur aduk dengan asset pribadi.

Pelaku usaha Kecil dan Menengah ini awalnya adalah para pelaku usaha yang sudah menjalankan aktifitas bisnisnya lebih dari 4 tahun dengan menggunakan dana bergulir melalui PNPM, dan sejak akhir tahun 2014 program ini ditutup oleh pemerintah, maka selanjutnya operasionalisasi diserahkan kepada UPT (Unit Pengelola Teknis) hingga saat ini, dan rata-rata dana yang dikelola UPT ini 
untuk kabupaten bintan setiap kecamatan rata-rata diatas 1 milyar rupiah.

Dalam pelaksanaannya pinjaman yang digulirkan ini diberikan kepada kelompok yang beranggotakan antara 5-10 orang, namun tanggungjawab dana tersebut adalah anggota masing-masing kelompok yang meminjam. Agar pengembalian dapat diawasi dengan baik maka tugas ketua kelompok yang akan mengkoordinasikan dengan cara mengumpulkan dan menyetor ke UPT. Setiap pelaku yang masuk dalam kategori lancar dalam pengembaliannya (tidak menunggak) maka biasanya akan diberikan insentif dan disebut Insentif Pembayaran Tepat Waktu (IPTW).

Fasilitas atau sarana dan prasarana yang dimiliki oleh pelaku usaha Kecil dan Menengah ini masih cukup memadai dan dapat dikembangkan lagi , dari beberapa kelompok yang ada sudah pernah mendapatkan bimbingan dari pemerintah daerah berupa pembuatan kemasan produk sehingga tampilannya bisa lebih menarik perhatian konsumen. Namun dari sisi yang lain seperti manajerialnya termasuk pemasaran produk masih sangat minim. Oleh karena itu perlu adanya pendampingan dan pelatihan dalam hal tersebut di atas melalui dana hibah Dipa Universitas Maritim Raja Ali Haji dalam bentuk pengabdian masyarakat. Kegiatan Pengabdian kepada Masyarakat ini bertujuan untuk membentuk usaha kecil yang produktif melalui penguasaan keterampilan dalam melakukan analisis usaha dan sekaligus mengembangkan usaha mereka

Kegiatan ini diharapkan dapat memberikan pemahaman dan keterampilan dalam membuat studi kelayakan usaha, dapat mahami aspek bahan baku, aspek produksi, aspek pemasaran, aspek keuangan serta dampak yang ditimbulkan secara ekonomi, dapat menyimpulkan bahwa usaha mereka layak untuk dilaksanakan, serta dapat menghitung penjualan paling minimal (break event) setiap harinya sehingga dapat ,menetapkan target penjualan untuk meminimalisir resiko kerugian.

\section{METODE PELAKSANAAN}

\section{Waktu dan Tempat}

Kegiatan dilaksanakan selama satu hari, yaitu tanggal 24 September 2019 di Kelurahan Tembeling Tanjung, Kecamatan Teluk Bintan, Kabupaten Bintan, Provinsi Kepulauan Riau

\section{Prosedur Pelaksanaan dan Analisis Data}

Metode pelaksanaan kegiatan ini adalah dalam bentuk Pelatihan. Sebelum dilakukan kegiatan pelatihan, terlebih dulu dilakukan pemetaan permasalahan dan kebutuhan melalui metode survei, FGD, dan diskusi dengan masyarakat. Metodologi pelaksanaan dalam pengabdian pada masyarakat ini dibagi menjadi 3 (tiga) tahap yaitu tahap pertama, tahap pelaksanaan dan tahap akhir. Pada tahap awal dilaksanakan observasi, dan wawancara secara langsung dengan para pelaku usaha dan aparat pemerintah setempat seperti ketua RW dan pihak Kelurahan, hal ini bertujuan untuk mengetahui gambaran masyarakat setempat dan untuk mengetahui permasalahan/kendala yang dihadapi oleh pelaku usaha.

Tahap kedua adalah tahap pelaksanaan berupa: (1) pelatihan motivasi kewirausahaan, Pada tahap ini, metode yang digunakan adalah berbagi pengalaman dengan para pelaku usaha. Baik pengalaman sukses dalam menjalankan usaha, pengalaman yang sedang merintis usaha, dan pengalaman yang gagal dalam melakukan usaha. Dengan adanya sharing session ini, diharapkan para peserta dapat mengambil pembelajaran dari setiap pengalaman yang dialami oleh para pelaku usaha; (2) pelatihan pembukuan keuangan sederhana yang dapat diaplikasikan oleh pelaku usaha kecil dan mikro, hal ini bertujuan untuk meningkatkan keterampilan dan pengetahuan mengenai manajemen 
keuangan usaha agar tidak tercampur antara keuangan keluarga dengan keuangan usaha, melalui pencatatan keuangan pelaku usaha dapat mengetahui perkembangan usahanya.

Tahap yang terakhir adalah tahap monitoring. Pada tahap ini, dilakukan metode coaching, dimana para peserta pelatihan menunjukkan hasil pencatatan keuangannya dengan menceritakan hambatan dan kesulitan yang dihadapi dalam melakukan proses pencatanan. Selain pencatatan keuangan, para peserta pelatihan juga diharapkan membagi rencana strategis usaha dalam jangka waktu menengah untuk menunjukkan inovasi-inovasi yang akan dilakukan yang dapat meningkatkan daya saing usaha.

\section{Target}

Target yang ingin dicapai pada program pengabdian masyarakat adalah adanya peningkatan dalam usaha karena sudah direncanakan dengan baik, meningkatkan pengembangan usaha meliputi yaitu jasa, yaitu pelatihan dan pendampingan untuk melakukan perbaikan manajemen wirausaha.

Memperhatikan analisis situasi dan penetapan prioritas masalah yang akan diselesaikan selama program pengabdian, dibagi menjadi tiga tahapan :

- Tahap 1, Perencanaan. Pada tahap ini, solusi yang ditawarkan adalah memberikan pengetahuan untuk membuka wawasan tentang manajemen wirausaha, pentingnya memahami bahwa melakukan studi kelayakan usaha bagai usaha yang akan dijalankan adalah perlu dilakukan agar dapat proyek atau usaha tersebut mendapatkan keuntungan atau kerugian.

- Tahap 2, Pelaksanaan. Pada tahap pelaksanaan ini, melakukan pelatihan, tanya jawab dan pendampingan manajemen usaha, tanya jawab pendampingan dan pengembangan usaha.
- Tahap 3, Evaluasi . Pada tahap ini, Evaluasi hasil pendampingan manajemen wirausaha, untuk memastikan bahwa studi kelayakan usaha tersebut sudah dapat dilaksanakan dengan baik.

\section{Luaran}

Setelah mengikuti kegiatan pelatihan ini, diharapkan para peserta pelatihan :

a. Para peserta mampu membuat pembukuan sederhana

b. Para peserta mampu membuat rencana bisnis sederhana yang dapat digunakan untuk memperoleh bantuan kredit mikro dari investor/bank

c. Para peserta mampu membenahi organisasi, memisahkan hubungan kekeluargaan dengan profesionalitas

d. Para peserta mampu mengelola tempat produksi menjadi lebih bersih dan layak, sehingga pembeli semakin tertarik dan tidak takut untuk membeli produk

e. Para peserta mampu memberlakukan manajemen waktu pekerja, khususnya bagi pekerja yang bertugas untuk belanja bahan baku dan pekerja produksi

f. Para peserta mampu membuat alternatif pembelian bahan baku dengan kualitas yang sama, namun dengan cara yang lebih efektif dan efisien

g. Para pesertra mampu melakukan optimalisasi penggunaan peralatan yang sudah ada, sehingga bisa digunakan juga oleh perempuan

\section{HASIL DAN PEMBAHASAN}

\section{Gambaran Kelurahan Tembeling \\ Tanjung}

Kelurahan Tembeling Tanjung adalah merupakan bagian dari Kecamatan Teluk Bintan yang berada di Kabupaten Bintan, dimana di sebelah Utara berbatasan dengan Desa Tembeling sebelah selatan, berbatasan dengan Kel. Kp.Bugis, Pemko Tanjungpinang; sebelah Timur, berbatasan dengan Desa Penaga; dan sebelah barat, 
berbatasan dengan Kelurahan Toapaya Asri. Transportasi masyarakat di wilayah Kecamatan Teluk Bintan, pada umumnya melalui jalan darat dan jalan laut, pembagian jalan dan panjang jalan di Kelurahan Se-Kecamatan. Secara ekonomi kehidupan masyarakat adalah nelayan dan bertani palawija, dan sebagian yang lain terutama ibu-ibu rumah tangga cukup banyak melakukan kegiatan dalam bidang ekonomi, baik pertanian, perdagangan, dan home industry.

\section{Kondisi Pelaku Usaha Mikro Kecil Menengah}

Dari survey yang telah dilakukan, bahwa mereka tidak pernah membuat analisis kelayakan daru usaha yang mereka lakukan, disebabkan karena ketidaktahuan bagaimana cara melakukannya. Terlebih para pelaku usaha tersebut rata-rata pendidikannya adalah lulus SMA. Beberapa dari pelaku usaha tersebut belum nampak perkembangan bisnis yang signifikan. Hal tersebut kelihatan dari pinjaman yang diajukan cenderung sama dari beberapa kali pencairan. Sejauh ini pelaku UMKM tersebut meminjam dana yang dikelola UPT Kecamatan Teluk Bintan (Eks PNPM)

\section{Pelatihan Studi Kelayakan Usaha}

A. Memberikan pelatihan dalam rangka meningkatkan manajemen wirausaha bagi pelaku usaha miko Kecil dan Menengah yang ada di Kelurahan Tembeling Tanjung, Kecamatan Teluk Bintan, Kabupaten Bintan, yaitu;

1. Membuat perencanaan terhadap usaha yang dijalankan, adalah tahapan yang sangat penting untuk menjalankan kegiatan usaha dengan membuat perencanaan yang matang, setidaknya mempunyai gambaran seperti apa hasil usaha pada bulan berikutnya. Dengan adanya gambaran hasil yang diharapkan maka akan tergambar pula bagaimana cara untuk mewujudkannya, seperti berapa target penjualan yang harus dicapai, bagaimana cara melakukan penjualan agar targetnya tercapai, serta bagaimana melakukan efisiensi biaya untuk menekan cost untuk mendapatkan laba yang maksimal.

2. Bahwa pada setiap cost yang dikeluarkan haruslah memberikan hasil atau imbalan yang lebih besar dari cost yang dikeluarkan sehingga kelebihan tersebut dapat dikategorikan sebagai laba dari sebuah usaha yang dijalankan. Itulah sebabnya agar margin menjadi tinggi maka efisiensi dalam sebuah usaha wajib dilaksanakan karena makin tinggi efisiensi yang dilakukan pada setiap kegiatan usaha akan memberikan hasil secara maksimal. Selain itu pelaku usaha seharusnya dapat mengetahui berapa cost sesungguhnya yang telah dikeluarkan. Dengan mengetahui cost yang sesungguhnya (real cost) maka pelaku usaha akan dapat mengetahui harga pokok dari produk yang dihasilkan.

3. Pemasaran, membantu menjelaskan bagaimana memasarkan produknya agar lebih dikenal lagi oleh masyarakat luas, selain masyarakat di lingkungan tempat tinggal pelaku usaha, dengan cara memanfaatkan media sosial yang ada. (WhatsApp, Line, BB, Facebook). Promosi dengan cara ini sangat mudah dan bisa dikendalikan langsung setiap saat oleh pelaku usaha, termasuk membuat banner kecil sebagai media promosi. Banner ini bertujuan untuk mempermudah customer mencari lokasi sehingga bisa membantu mempromosikan mengenai produk apa saja yang dijual.

B. Memberikan pendampingan kepada para pelaku usaha dalam menyusun studi kelayakan usaha mereka masing-masing, oleh karena latar belakang usaha mereka yang berbeda-beda, maka dalam pelatihan ini menggunakan contoh bagaimana cara menghitung kelayakan usaha yang bergerak dalam bidang produksi kerupuk ikan, karena secara umum pelaku UKM 
adalah yang bergerak dalam bidang usaha kerupuk ikan tersebut, dan dari pemahaman ini diharapkan akan dapat diterapkan pada usaha mereka masingmasing.

Secara umum pelaku usaha mengerti tentang konsep kelayakan dari sebuah usaha, di mana untuk dapat terus bertahan dan berkembang sebuah usaha harus dibuatkan sebuah studi atau analisis kelayakannya sebelum menjalanannya, karena akan sangat berpengaruh terhadap keberhasilan apakah usaha tersebut semakin berkembang atau malah semakin berkurang.

C. Penghitungan penjualan paling minimal agar usaha tidak mengalami kerugian.

Sebagian besar pelaku usaha tidak bisa menentukan berapa jumlah penjualan paling minimal agar usaha tidak mengalami kerugian, dan mereka cukup berpendapat bahwa yang penting hasil produksi terjual habis. Padahal produk yang habis terjual belum tentu akan mengalami laba, apalagi kalau harga jualnya sama atau lebih rendah dari harga pokoknya sudah dapat dipastikan bahwa usaha akan mengalami kerugian. Oleh karena itu para pelaku usaha harus dapat menentukan penjualan minimal secara sederhana melalui laporan laba rugi.

D. Realisasi hasil Pelatihan Studi Kelayakan Usaha

Realisasi yang didapat dari pendampingan dan pembinaan kepada pelaku usaha Kecil dan Menengah ini adalah ini adalah :

1. Adanya pemahaman yang diperoleh oleh pelaku usaha, dimana pada materi yang diberikan dilengkapi dengan latihan-latihan yang sangat sederhana sehingga mudah untuk dipahami oleh seluruh peserta. Walaupun bentuk usaha yang mereka lakukan berbeda satu sama lain, namun dengan adanya pemahaman dasar pembukuan ini akan dapat diaplikasikan secara langsung dengan usaha mereka.

2. Salah satu yang menjadi persoalan penting dalam menjalankan usaha adalah informasi mengenai harga pokok produksi (HPP), di mana dengan mengetahui perhitungan HPP ini akan memudahkan para pelaku usaha untuk dapat memainkan harga jualnya, dapat menentukan berapa margin yang diharapkan sehingga dapat terhindar dari kerugian. Kepada para peserta juga diajarkan bagaimana menghitung harga pokok produksi untuk industri kerupuk dengan menggunakan asumsi standar yang sederhana, setidaknya mereka sudah dapat memahami mana yang merupakan aset lancar yang dapat dibebankan secara langsung dan aset tetap yang pembebanannya dengan menggunakan penyusutan aset tetap.

3. Pada pelatihan ini kepada peserta juga diajarkan bagaimana cara menghitung dan menentukan penjualan paling minimal yang harus dilakukan agar usaha tidak mengalami rugi, hal sangat perlu dilakukan oleh pelaku usaha mengingat sebagian besar para pelaku usaha tidak memperhatikan dan tidak tahu bagaimana cara menentukan penjualan paling minimal tersebut. Secara umum cara menghitungnya adalah dengan melakukan analisa break event point.

Dengan mengetahui penjualan paling minimal ini para pelaku usaha sudah bisa membuat suatu perencanaan penjualan dengan tepat, membuat strategi-strategi dalam meningkatkan penjualan, atau mungkin merekrut karyawan yang khusus untuk memasarkan produk. Strategi seperti ini sangat diperlukan untuk membesarkan usaha dan sangat dimungkinkan untuk melakukan diversifikasi produk, dan bila hal ini sudah tercapai maka langkah selanjutnya yang dapat dilakukan adalah :

a. Menambah modal kerja untuk menaikkan produksi atau membuat produk yang baru.

b. Menambah modal kerja bisa dari dana sendiri atau melakukan pinjaman kepada pihak ketiga (UPT atau Bank) 
(Rivai 2013)

c. Hindari berurusan dengan pemodal/kreditur yang tidak legal karena akan semakin memberatkan pelaku usaha, dimana pembebanan bunga pinjaman yang sangat tinggi dan tidak realistis dengan hasil yang akan diterima.

Tahapan pelaksanaan pengabdian yang sudah dilakukan sampai saat ini adalah pada tahapan:

- Membantu dalam pelatihan studi kelayakan usaha, sehingga pelaku usaha dapat mengetahui usaha yang sedang berjalan atau yang sedang diusahakan secara finansial layak atau tidak untuk dilaksanakan.

- Membantu pelaku usaha dalam menghitung harga pokok produksi secara benar, sehingga dapat mengukur dengan pasti berapa margin yang akan diperoleh dibandingkan dengan harga jualnya.

- Membantu pelaku usaha untuk menentukan penjualan paling minimal sehari atau sebulan bergantung pada periodesasi laporan keuangan yang disusun, hal ini akan sangat membantu pelaku usaha untuk menjaga agar jangan usaha yang dijalankan menjadi rugi.

Hasil yang diharapkan pada pelatihan ini adalah adanya kejelasan mengenai informasi usaha layak atau tidak untuk dilaksanakan dan bagaimana mengatasi bila usaha mengalami rugi, adanya kejelasan mengenai penentuan harga pokok penjualan dan adanya kejelasan mengenai berapa penjualan paling minimal yang harus dilakukan agar usaha tidak mengalami rugi.

\section{Evaluasi Yang Dilakukan Kepada Pelaku Usaha : \\ Analisis Kelayakan Usaha}

Setiap usaha diharapkan mempunyai analisis kelayakan usaha untuk dapat menilai bahwa usaha yang akan dan sedang dijalankan ini memberikan simpulan yang layak untuk jalankan dan dikembangkan, dan dengan demikian para pelaku usaha dapat menjadi usahawan yang mandiri, berkeyakinan yang kuat bahwa usahanya akan dapat berkembang dengan baik, apalagi ditambah dengan pinjaman modal kerja sehingga para pelaku usaha maka perkembangan usaha tersebut akan berkembang secara signifikan (Kasmir dan Jakfar 2003; Dewi dan Yadnya 2013).

Selain itu dengan analisis studi kelayakan usaha ini juga dapat memberikan informasi mengenai kekuatan, kelamahan, peluang, dan ancaman atau biasa disebut dengan analisis SWOT yaitu strengths, weaknesses, opportunities, dan threats (Yusron 2005). Analisis SWOT adalah metode perencanaan strategis yang digunakan untuk mengevaluasi kekuatan (strengths), kelemahan (weaknesses), peluang (opportunities), dan ancaman (threats) dalam suatu proyek atau suatu spekulasi bisnis. (Mashitoh 2014). Analisis SWOT dapat diterapkan dengan cara menganalisis dan memilah berbagai hal yang mempengaruhi keempat faktornya, kemudian menerapkannya dalam gambar matrik SWOT, di mana aplikasinya adalah bagaimana kekuatan (strengths) mampu mengambil keuntungan (advantage) dari peluang (opportunities) yang ada, bagaimana cara mengatasi kelemahan (weaknesses) yang mencegah keuntungan (advantage) dari peluang (opportunities) yang ada, selanjutnya bagaimana kekuatan (strengths) mampu menghadapi ancaman (threats) yang ada, dan terakhir adalah bagaimana cara mengatasi kelemahan (weaknesses) yang mampu membuat ancaman (threats) menjadi nyata atau menciptakan sebuah ancaman baru. Dari semua itu diharapkan dapat memberikan informasi tentang perkembangan usaha, kinerja perusahaan yang bermanfaat bagi pengguna rangka membuat keputusankeputusan ekonomi serta menunjukkan pertanggungjawaban manajemen atas penggunaan sumber daya yang 
dipercayakan kepada mereka. Namun nyatanya praktek akuntansi keuangan pada Usaha Kecil dan Menengah (UKM) masih sangat rendah (Putri 2013).

Dari hasil survey yang dilakukan, masalah kurangnya kemampuan pelaku UKM dalam bidang pengelolaan usaha juga termasuk kendala yang dihadapi UKM, antara lain rendahnya pendidikan dan kurangnya pemahaman pelaku UKM tersebut dalam bidang manajemen keuangannya. Biasanya kelayakan sebuah usaha bagi UKM masih dilakukan dengan cara-cara sederhana, dan malah tidak sedikit pelaku usaha melakukannya dengan cara membayangkan saja, langsung aksi, walaupun dari ukuran sukses tidaknya akan sangat bergantung pada sejauh mana para pelaku usaha ini mempromosikan produknya dan menjagai kualitas agar terus mendapat apresiasi yang positif dari para pelanggannya.

\section{Perhitungan Harga Pokok Penjualan}

Pengertian Harga pokok penjualan (HPP) adalah jumlah semua pengeluaranpengeluaran langsung atau tidak langsung yang berhubungan dengan perolehan, penyiapan dan penempatan barang agar dapat dijual. Dengan istilah lain dapat didefinisikan bahwa HPP adalah harga yang harus dibayar untuk memperoleh suatu barang, dalam prakteknya untuk usaha dagang harga pokok penjualan terdiri dari harga faktur ditambah biaya angkut, sementara untuk pabrikasi ditambah biaya produksinya (Haryono 2011).

Usaha yang telah dibuat tentunya ingin berkembang dan terus berkembang serta terus menjaga kelangsungan hidupnya, untuk itu pihak pelaku usaha perlu membuat kebijakan yang mengacu pada terciptanya efisiensi dan efektivitas kerja.

Kebijakan tersebut dapat berupa penetapan harga pokok penjualan, yaitu dengan cara menekan biaya produksi serendah mungkin namun tetap menjaga kualitas dari barang atau produk yang dihasilkan, sehingga harga pokok produk satuan yang dihasilkan oleh pelaku usaha lebih rendah dari yang sebelumnya.

Kebijakan seperti ini sangat bermanfaat bagi entitas usaha untuk menetapkan harga jual yang tepat dengan laba yang ingin diperoleh pelaku usaha, sehingga pelaku usaha tersebut dapat bersaing dengan pelaku usaha lainnya yang memproduksi produk sejenis. Hal ini tentunya tidak terlepas dari tujuan didirikannya usaha yaitu agar modal yang ditanamkan dan dipinjam dalam pelaku usaha dapat terus berkembang atau dengan kata lain mendapatkan laba semaksimal mungkin.

Kesalahan dalam perhitungan harga pokok penjualan dapat mengakibatkan penentuan harga jual pada suatu perusahaan menjadi terlalu tinggi atau terlalu rendah. Kedua kemungkinan tersebut dapat mengakibatkan keadaan yang tidak menguntungkan bagi pelaku usaha, karena dengan harga jual yang terlalu tinggi dapat mengakibatkan produk yang ditawarkan akan sulit bersaing dengan produk sejenis yang ada di pasar, sebaliknya jika harga jual produk terlalu rendah akan mangakibatkan laba yang diperoleh rendah pula, jadi menghitung harga pokok penjualan adalah hal yang wajib bagi setiap pelaku usaha.

\section{Perhitungan Penjualan Paling Minimal (Break Event)}

Break Even Point (BEP) adalah titik di mana suatu perusahaan atau bisnis dalam keadaan belum memperoleh keuntungan, namun tidak pula merugi. BEP juga dapat diartikan sebagai sebuah analisis untuk menentukan dan mencari jumlah barang atau jasa yang harus dijual kepada konsumen pada harga tertentu guna menutupi biaya-biaya yang timbul dan memperoleh keuntungan (Sugiyono 2007; sugiyono 2016).

BEP juga bisa disebut sebagai suatu keadaan di mana dalam operasi perusahaan, perusahaan tersebut tidak mendapatkan laba dan juga tidak mengalami kerugian. BEP memang dipakai untuk mengetahui apakah perusahaan 
Tabel 1 Hasil Pencapaian Pengabdian Masyarakat

\begin{tabular}{|c|c|c|c|c|}
\hline No & URAIAN & SEBELUM & SESUDAH & $\begin{array}{l}\text { CAPAIAN } \\
\text { KEGIATAN }\end{array}$ \\
\hline 1 & $\begin{array}{l}\text { Membantu dalam pelatihan } \\
\text { penyusunan studi kelayakan } \\
\text { usaha, sehingga pelaku usaha } \\
\text { dapat mengetahui dengan } \\
\text { apakah usaha mereka layak } \\
\text { atau tidak } \\
\text { dilaksanakan }\end{array}$ & $\begin{array}{l}\text { Pelaku usaha } \\
\text { tidak pernah } \\
\text { membuat } \\
\text { studi } \\
\text { kelayakan } \\
\text { usaha }\end{array}$ & $\begin{array}{lr}\text { Sudah } & \text { dapat } \\
\text { menghitung } & \\
\text { kelayakan usaha } \\
\text { secara sederhana, } \\
\text { sehingga lebih } \\
\text { yakin r dalam } \\
\text { menjalankna usaha } \\
\text { mereka }\end{array}$ & $100 \%$ \\
\hline 2 & $\begin{array}{l}\text { Membantu pelaku usaha } \\
\text { dalam menghitung harga } \\
\text { pokok produksi secara benar, } \\
\text { sehingga dapat mengukur } \\
\text { dengan pasti berapa margin } \\
\text { yang akan diperoleh } \\
\text { dibandingkan dengan harga } \\
\text { jualnya }\end{array}$ & $\begin{array}{l}\text { Belum dapat } \\
\text { menghitung } \\
\text { harga pokok } \\
\text { penjualan dari } \\
\text { usaha yang }\end{array}$ & $\begin{array}{l}\text { Sudah } r \text { dapat } \\
\text { menghitung harga } \\
\text { pokok penjualan } \\
\text { per unit untuk } \\
\text { usaha kerupuk } \\
\text { ikan dalam periode } \\
\text { satu bulan }\end{array}$ & $100 \%$ \\
\hline 3 & $\begin{array}{l}\text { Membantu pelaku usaha } \\
\text { untuk menentukan penjualan } \\
\text { paling minimal sehari atau } \\
\text { sebulan bergantung pada } \\
\text { periodesasi laporan } \\
\text { keuangan yang disusun, hal } \\
\text { ini akan sangat membantu } \\
\text { pelaku usaha untuk menjaga } \\
\text { agar jangan usaha yang } \\
\text { dijalankan menjadi rugi. }\end{array}$ & $\begin{array}{l}\text { Belum dapat } \\
\text { menentukan } \\
\text { penjualan } \\
\text { paling } \\
\text { minimal } \\
\text { (break event) } \\
\text { dari usaha } \\
\text { yang }\end{array}$ & 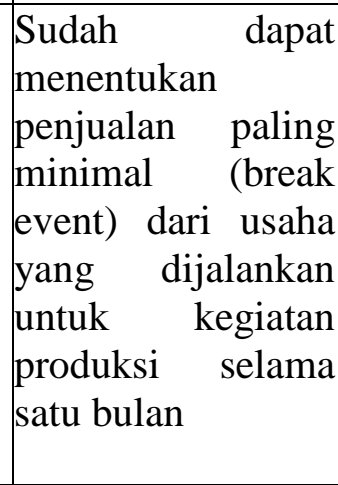 & $100 \%$ \\
\hline
\end{tabular}

mencapai BEP atau tidak. Akan tetapi analisa BEP juga bisa dimanfaatkan untuk mengetahui berbagai tingkat volume penjualan dan hubungannya dengan kemungkinan mendapat laba menurut tingkat penjualan yang bersangkutan (Suliyanto 2010).

\section{Solusi}

Strategi Peningkatan Adalah cara yang dilakukan dalam sebuah kegiatan untuk membuat perbaikan dalam hal kemakmuran yang dirasakan oleh masyarakat dalam menjalankan usahanya, di mana usaha tersebut dapat meningkatkan taraf hidupnya dari pendapatan usaha yang diperoleh agar kegiatan mereka berjalan dengan lancar.

Upaya penggerakan sumber daya adalah mengembangkan potensi ekonomi masyarakat dalam meningkatkan produktivitas masyarakat, sehingga baik sumber daya manusia maupun sumber daya alam di sekitar dapat dikembangkan dengan maksimal sehingga dibutuhkan produktivitas dalam menjalankan usaha, dengan demikian masyarakat dan lingkungan mampu secara partisipatif menghasilkan dan menumbuhkan nilai tambah yang meningkatkan kemakmuran serta kesejahteraan mereka. Hal itu membutuhkan daya pikir kreatif, masyarakat tidak saja mengerjakan usaha yang mudah-mudah saja tetapi masyarakat harus memikirkan mengelola sumber daya alam dengan menggunakan konsep produksi sehingga hasil yang diperoleh dapat meningkatkan kesejahteraan keluarga. 
Kegiatan produksi merupakan kegiatan yang berhubungan dengan penciptaan/pembuatan barang, jasa atau kombinasinya, melalui proses transformasi dari masukan sumber daya produksi menjadi keluaran yang diinginkan. Melalui kegiatan produksi, segala sumber daya masukan perusahaan diintegrasikan untuk menghasilkan keluaran yang memiliki nilai tambah. Produk yang dihasilkan dapat berupa barang atau akhir, barang setengah jadi ataupun jasa. Bagi perusahaan berorientasikan laba, produk ini selanjutnya dijual untuk memperoleh keuntungan dan sumber dana yang baru bagi kegiatan operasi berikutnya. Kegiatan produksi merupakan kegiatan kompleks, tidak saja mencakup pelaksanaan fungsi manajemen dalam mengkordinasikan berbagai kegiatan atau bagian dalam mencapai tujuan produksi, tetapi juga mencakup kegiatan teknis untuk menghasilkan suatu produk yang memenuhi spesifikasi yang diinginkan, dengan proses produksi yang efisien dan efektif serta dengan mengantisipasi perkembangan teknologi dan kebutuhan konsumen di masa yang akan datang. Oleh karena itu, pengetahuan yang baik tentang manajemen produksi perlu dimiliki oleh semua pihak yang terlibat langsung dalam proses pembuatan produk sesuai dengan peranan masing-masing.

Meningkatkan Produktivitas dan Pemasaran yang layak memang tak semudah yang kita bayangkan, produkproduk yang dibuat oleh masyarakat harus memiliki standarisasi agar produk tersebut dapat diterima di pasar nasional maupun internasional, hal ini menjadi sebuah tantangan bagi pemerintah Kabupaten Bintan khususnya untuk melakukan indentifikasi setiap pelaku Usaha Produktif yang ada di Kabupaten Bintan, untuk dikaji permasalahan yang ada di lapangan di dalam mengembangkan usaha yang mereka jalani, serta memberikan pelatihan-pelatihan dan penguatan bagi pelaku Usaha Ekonomi Masyarakat Produktif agar produksi dan efektifitas kerja mereka dapat berkembang dengan maksimal, sehingga dapat meningkatkan kesejahteraan masyarakat, sesuai dengan visi dan misi Kabupaten Bintan, yaitu terwujudnya Kabupaten Bintan yang Madani dan Sejahtera melalui pencapaian Bintan gemilang 2025.

Adapun pelaku usaha pada program pengabdian masyarakat ini adalah para Pelaku Usaha Mikro Kecil dan Menengah di Kelurahan Tembeling Tanjung Kecamatan Teluk Bintan dengan bentuk usaha yang beraneka macam, seperti usaha kerupuk ikan, warung kelontong, bengkel, perkebunan palawija, tanaman hias, gorengan, menjahit, konter HP/pulsa, dan warung nasi.

Hal yang tidak kalah pentingnya yang selalu dilanggar adalah para pelaku usaha ini tidak menerapkan konsep entitas, yaitu memisahkan memisahkan antara aset perusahaan dengan aset pribadi, dan yang terjadi adalah di mana aset perusahaan juga adalah aset pribadi sehingga akan sangat sulit dalam penyusunan laporan keuangan termasuk kesulitan dalam menghitung harga pokok produksi secara benar.

\section{KESIMPULAN}

Kegiatan pengabdian yang sudah dilakukan berupa manajemen wirausaha yang meliputi analisis studi kelayakan usaha atau feasibilty study, penghitungan harga pokok penjualan (HPP) dari produksi yang dihasilkan, dan menentukan berapa jumlah penjualan yang paling minimal yang harus diperoleh, untuk menjaga jangan sampai terjadi kerugian. Kegiatan ini dilaksanakan di Kelurahan Tembeling Tanjung Kecamatan Teluk Bintan Kabupaten Bintan pada tanggal 24 September 2019 yang diikuti oleh Pelaku usaha Mikro Kecil dan Menengah yang berasal dari Kecamatan Teluk Bintan dan mereka juga selama ini adalah partner kerja dari PNPM di mana saat ini dana tersebut dikelola oleh Unit Pelaksana Kegiatan (UPK). Mereka berasal dari berbagai usaha, dalam pelatihan ini 
memberikan pemahaman dasar bagaimana menganalisis suatu kelayakan usaha, selain itu melakukan penghitungan harga pokok penjualan, dan menentukan jumlah penjualan yang paling minimal yang harus dilakukan, dimana selama ini semua dari pelaku usaha tersebut tidak pernah membuat hal tersebut. Setelah mengikuti pelatihan ini diharapkan sudah terbentuk suatu pemahaman dasar bagaimana membuat suatu analisis kelayakan yang sederhana, mengetahui apa yang menjadi kekuatan dan kelemahan, mengetahui peluang-peluang usaha serta ancamannya sehingga lebih berhati-hati dalam melangkah.

\section{DAFTAR PUSTAKA}

Haryono, Y. A. 2011. Dasar-dasar Akuntansi. Edisi 1, STIEYKPN. Yogyakarta

Ikatan Akuntan Indonesia. 2016 Standar Akuntansi Keuangan Entitas Mikro Kecil menengah.

Kasmir dan Jakfar. 2003. Studi Kelayakan Bisnis. Edisi Revisi. Cetakan ke-8. Jakarta: Kencana.

Dewi, N.L.P.M.K. dan Yadnya, I.P. 2013. Studi Kelayakan Investasi dari Aspek Finansial untuk Pendirian Naya Salon Denpasar. E-Jurnal Manajemen Universitas Udayana, pp: $32-50$.

Mashitoh 2014. Studi Kelayakan Agroindustri Fillet Ikan Nila di Kabupaten Mesuji. Jurnal Teknologi Industri dan Hasil Pertanian 19 (1)

Rivai, V. 2013. Commercial Bank Management: Manajemen Perbankan Dari Teori Ke Praktik. Edisi 1.Cetakan 1. Jakarta: Rajawali Pers.

Sugiyono. 2007. Metode Penelitian Bisnis. Bandung: IKAPI.

Sugiyono. 2016. Metode Penelitian Kombinasi(Mixed Methods). Cetakan ke 8. Penerbit Alfabeta Bandung

Suliyanto. 2010. Teknik Proyeksi Bisnis. Yogyakarta: ANDI
Wiagustini, NLP. 2010. Dasar-Dasar Manajemen Keuangan. Denpasar: Udayana University Press.

Putri, NPY. 2013. Analisis Kelayakan Investasi Pembangunan Ruko Aurelia Dari Aspek Keuangan Pada Pt. Bahtera Mitra Sejahtera Di Samarinda. Fakultas Ilmu Sosial dan Politik Universitas Mulawarman, Samarinda. eJournal Pemerintahan Integrattif 1(2) : 164-181.

Yusron. 2005. Studi Kelayakan Pendirian Pabrik Tepung Ikan di PT. X Di Kabupaten Tulung Agung. Universitas Airlangga. 